\title{
Epidemiology and Genotyping of Patients with Lysosomal Storage Disease in Malaysia.
}

Affandi Omar ( $\square$ fendi.omar@moh.gov.my)

Institute for Medical Research https://orcid.org/0000-0001-5861-6607

Rosnani Mohamed

Institute for Medical Research

Fatimah Diana Amin Nordin

Institute for Medical Research

Norashareena Mohamed Shakrin

Institute for Medical Research

Sofwatul Mukhtaroh Nasohah

Institute for Medical Research

Nor Shuhaili Salleh

Institute for Medical Research

Nor Azimah Abdul Azize

Institute for Medical Research

Siti Aishah Abdul Wahab

Institute for Medical Research

Seok Hian Lua

Institute for Medical Research

Yusnita Yakob

Institute for Medical Research

Julaina Abdul Jalil

Institute for Medical Research

Research

Keywords: Lysosomal storage disease, mucopolysaccharidoses, sphingolipidoses, enzyme assay, Malaysia

Posted Date: August 3rd, 2021

DOl: https://doi.org/10.21203/rs.3.rs-757575/v1

License: (c) (i) This work is licensed under a Creative Commons Attribution 4.0 International License. Read Full License 


\section{Abstract}

Background: Lysosomal storage disorders (LSD) are storage disorders involving malfunction of degradation enzymes in lysosome. More than 50 types of LSD have been discovered, which includes the group of mucopolysaccharidoses (MPS), sphingolipidoses, oligosaccharidoses, mucolipidoses, lipoprotein storage disorders, lysosomal transport defects and neuronal ceroid lipofuscinoses and others. The aims of this study were to calculate the birth prevalence and carrier frequency of LSDs in the Malaysian population; to compare our results with reported epidemiologic data from other populations, and to describe the mutation spectrum in Malaysia. From 2008 to 2017, 2.1\% (92/4338) suspected patients were diagnosed with LSD.

Results: The prevalence of LSD in Malaysia was 1/231,904 live births. The combined prevalence of MPS was 1/292,401 with its subtype of MPS II presented the highest calculated birth prevalence of $1 / 221,425$. Within the group of sphingolipidoses, the combine prevalence was $1 / 770,777$ with Fabry as the most common disorder with calculated prevalence of 1/193,203 followed by metachromatic leukodystrophy (MLD) (1/494,514). MLD is more common among people of Iban ethnicity with the prevalence of 1/6,981. Pompe and mucolipidoses type II are the less common subtypes of LSD with a prevalence of $1 / 1,694,634$ and $1 / 2,229,516$, respectively.

Conclusion: Overall, although the prevalence of LSD in Malaysia may be underestimated, the prevalence of MPS is consistent with other reported in East Asian countries.

\section{Background}

Lysosomal storage disorders (LSD) involve the malfunction of degradation enzymes in lysosome. More than 50 types and sub-types of LSD have been discovered which can be divided into the following groups; (i) mucopolysaccharidoses (MPS), (ii) sphingolipidoses, (iii) oligosaccharidoses, (iv) mucolipidoses, (v) lipoprotein storage disorders, (vi) lysosomal transport defects and (vii) neuronal ceroid lipofuscinoses and others. Within its vast classification, several subtypes were discovered within each group. For example, in MPS group, there are six subtypes: MPS I, MPS II, MPS III (with sub subtype of MPS IIIA, MPS IIIB, MPS IIIC, MPS IIID), MPS IV (with sub subtype of MPS IVA and MPS IVB), MPS VI and MPS VII. As for Fabry disease, Gaucher disease, ganglioside monosialic $1\left(\mathrm{GM}_{1}\right)$ gangliosidoses, ganglioside monosialic $2\left(\mathrm{GM}_{2}\right)$ gangliosidoses, metachromatic leukodystrophy (MLD) and Krabbe disease, all were categorised under sphingolipidoses group. Although rare in individuals, collectively they are relatively common with a prevalence ranging from 12 to 25 per 100,000 live births [1, 2]. While a preliminary study on selective screening of mucopolysaccharidoses in Malaysia was carried out in 2014-2016 [3, 4], the prevalence of LSD in Malaysia is still unidentified.

Patients with LSD may appear normal at birth but deteriorate in the first years of life. They can present with coarse facies, mental retardation, hepatosplenomegaly, dysostosis multiplex, valvular heart disease, respiratory pathology, and renal impairment. Affected patients may die during their adolescences period if untreated [5].

LSD is mostly an autosomal recessive disorder, except for Fabry disease and MPS II which are X-linked and noted to be more common in consanguineous marriage [6]. For the treatment, enzyme replacement therapy (ERT) has been extensively used in some of LSD such as Fabry, Gaucher and Pompe diseases. It has been proven that enzyme replacement therapy (ERT) can improve the quality of life and prognosis of these patients [7-9]. Therefore, early diagnosis is crucial for a successful treatment.

The rarely involvement of policymaker in dealing with LSD due to lack of understanding for these diseases among general population has contributed to the urgency for the prevalence and mutation spectrum in Malaysia [10]. Design and implementation of preventative programs such as premarital testing and neonatal screening can be proposed to the health authority i.e., Ministry of Health Malaysia. This study described the birth prevalence of LSD and its carrier frequencies in Malaysian population. Our estimated prevalence was compared to four other countries namely Czech Republic, United Arab Emirates, Northern Portugal, and The Netherlands. Furthermore, the unique mutation spectrum among Malaysian population was also being reported.

\section{Materials And Methods}

\section{Study design}

This was a retrospective, laboratory records-based analysis of all patients diagnosed with LSDs at the Institute for Medical Research (IMR) between 2008 and 2017.

\section{Study Population}

Located at South East Asia, Malaysian land is divided into two parts, namely Malaysian Borneo and Peninsular Malaysia. Region of Sabah and Sarawak as well as one federal territory (Labuan) are located at Malaysian Borneo while other 11 states and two federal territories (Kuala Lumpur and Putrajaya) are situated at peninsular Malaysia. The study area was divided into six main regions: i) Central region includes Federal Territory of Kuala Lumpur, Federal Territory of Putrajaya, State of Selangor and Negeri Sembilan; ii) Northern region consists the state of Perak, Penang, Kedah and Perlis; iii) The state of Kelantan, Terengganu and Pahang forming the Eastern region; iv) Southern region includes state of Melaka and Johor and v) The region of Sabah and the region of Sarawak was considered as separate region considering its larger land mass comparing to peninsular Malaysia. In 2018, the population of Malaysia was estimated to be 32 million people [11]. Malaysian is ethnically diverse, with majority of Malay, Chinese, Indian, Orang Asli (aborigines' people) and the natives from Sarawak and Sabah. The minorities include Sikh, Punjabi, Portuguese and others. Despite of ethnic diversity, inter-race marriages are less common than intra-race ones [11].

\section{Sampling methods}


Data from individuals who had been tested for mucopolysaccharidoses (MPS) screening (Glycosaminoglycans [GAGs] quantitation and characterization) and/or urinary oligosaccharidoses and/or Pompe screening and/or multiplex LSD screening from 2008 to 2017 were included in this retrospective study.

\section{Variables and measurement}

Variable measurand in this study includes gender, ethnicity, regional, age at diagnosis, frequency of LSD, LSD group, and LSD type.

\section{Data collection}

Laboratory findings including results interpretation were retrieved from the laboratory records and reviewed. Patients were included in the study only if the diagnosis of LSD was confirmed with both screening and confirmatory testing.

\section{Laboratory processes and tests}

All laboratory diagnoses from screening to confirmatory were done in IMR which is the reference centre providing comprehensive tests for LSD. We received samples from all healthcare facilities including private hospitals throughout Malaysia. There were four screening tests for LSD: (i) urinary quantitation of GAGs using spectrophotometry and characterization of GAGs using one-dimension high resolution electrophoresis for determination of MPS subtype; (ii) urinary qualitative oligosaccharidoses by thin layer chromatography (TLC) method for screening of a-mannosidosis, a-fucosidosis, $\mathrm{GM}_{1}$ gangliosidosis, $\mathrm{GM}_{2}$ gangliosidosis, $\beta$-mannosidosis, Pompe/Glycogen Storage Disease Type II and Schindler disease; (iii) Pompe screening by fluorometry method using fluorometer for quantitation of a-glucosidase enzyme in dried blood spots (DBS); and (iv) multiplex enzyme assay in DBS using tandem mass spectrometry for screening of Niemann-Pick disease, Fabry disease, Pompe disease, Krabbe disease and Gaucher disease. The confirmatory diagnoses of LSD were either by enzyme assay for the absence or reduction of enzyme activity in leukocytes or plasma, or by mutational analysis of respective genes. PCR and bidirectional sequencing were applied to identify mutations and were carried out at accredited genetic laboratory.

\section{Data Analysis}

Disease birth prevalence was expressed as number of patients per 100,000 live births and calculated using the method reported by Poorthuis et al. [2]. Briefly, the prevalence was set as the total number of Malaysian patients with the specific disease divided by the total number of Malaysian live births during the birth period.

The birth period was defined as the time interval between year of birth of the oldest patient and year of birth of the youngest patient. Live births per year were obtained from the Department of Statistics Malaysia (https://www.dosm.gov.my). We used Pinto et al. [1] method to estimate disease birth prevalence when only a single patient was diagnosed with the disease, using the number of live births between 1974 and 2017 [1]. The overall prevalence was calculated from the total prevalence of each LSD phenotype.

Comparisons between countries were evaluated by selecting four countries which are United Arab Emirates representing Asian population; while Czech Republic, The Netherlands, and Northern Portugal representing Caucasian population. These countries were chosen due to its high frequency of LSD cases within its population.

As for spectrum mutation analysis, the sequencing results obtained were evaluated by aligning with human reference sequence retrieved from GenBank ${ }^{\circledR}$ (http://www.ncbi.nlm.nih.gov) database; and the pathogenic and likely pathogenic variants selection were performed by comparing with available information from publication as well as clinical and population frequency databases. Carrier frequency was calculated using the Hardy-Weinberg equation (Strachan and Read 2004) online calculator at http://perinatology.com/calculators/Hardy-Weinberg.htm

Descriptive statistics were presented as number and percentage for categorical variables. Patients with missing gender and age data were excluded from descriptive statistics. Median with interquartile range (IQR) were used for data that were not normally distributed. Data collected was tabulated using IBM SPSS statistics version 22 software packages (IBM Corp. Released 2013. IBM SPSS Statistics for Windows, Version 22.0. Armonk, NY: IBM Corp).

\section{Results}

\section{Patient demographics}

Demographics of Malaysian patients is presented in Table 1. Out of 4338 patients who were clinically suspected of having LSD, 92 (2.1\%) were diagnosed with 15 different subtypes. The gender distribution was almost balance between males and females with $55.4 \%$ and $44.6 \%$, respectively. Most patients (93.6\%) were below the age of 18 years at diagnosis. Individuals at or over the age of 18 years were considered as adults. Nearly $50 \%$ of adult cases were diagnosed with adult form of MPS IV. Most of our patients (44.6\%) were originated from central region. In general, the age median at diagnosis was 2.54 years, ranging from 0.01 (4 days) to 40 years. Comparing to this, MPS Type IVA patients were diagnosed 7 years late whereas MPS Type I patients were diagnosed as early as 1 year of age.

\section{Distribution of LSD subtypes}

We diagnosed fifteen subtypes of LSD. The MPS (51.1\%) was the most common group followed by sphingolipidoses (33.7\%), Pompe (9.8\%) and mucolipidoses type II (5.4\%). No patient was diagnosed with a-mannosidosis, $\beta$-mannosidosis, Schindler disease, MPS Type IIIC/IIID nor MPS Type VII.

In the MPS group, MPS Type II (31.9\%) represented more than quarter of all MPS cases followed by MPS Type IVA (21.3\%), MPS Type VI (19.1\%), MPS Type I (14.9\%), MPS Type IIIA (8.5\%) and MPS Type IIIB (4.3\%). As for the sphingolipidoses group, out of 31 patients, nearly half of the cases were diagnosed as 
Metachromatic Leukodystrophy (MLD) (48.4\%), followed by fucosidosis (12.9\%), GM 1 gangliosidosis (12.9\%), Gaucher (12.9\%), GM 2 gangliosidosis (Sandhoff) (6.5\%), Krabbe (3.2\%) and Fabry (3.2\%). Nine (9) patients were diagnosed with Pompe disease, with majority of them were infantile onset.

The prevalence of LSD in Malaysia, and its comparison with four other countries, is shown in Table 2. The prevalence of LSD among Malaysian was 0.43 per 100,000 live births or 1 in 231,904 live births. This rate was 26 -fold lower compared to UAE (Asian) and Northern Portugal (European). Similar to this study, the most prevalent LSD in Northern Portugal, the Netherlands and the Czech Republic were sphingolipidoses and MPS. There were between-country differences in the prevalence of individual types of diagnosed LSD, not only between Malaysia, UAE and European countries, but also between UAE and the European countries. For example, Fabry and MPS II were the most prevalent in Malaysia; while $\mathrm{GM}_{2}$ and Pompe were common in Northern Portugal and the Netherlands respectively. Among Asian population, $\mathrm{GM}_{1}$ is five times higher is UAE compared to Malaysian but MPS II is relatively high in Malaysia compared to UAE.

We found that Chinese were 17 times more likely to have Pompe disease compared to others (OR $16.98,95 \% \mathrm{Cl} 3.52-81.88, \mathrm{p}<0.05)$. We noted out of 9 Pompe patients, 7 were Chinese and the c.1935C > A p.(Asp645Glu) was the pathogenic mutation detected in all of them.

\section{Mutations Analysis}

Sequencing analyses of the GAA, FUCA1, GBA, ARSA and GLNS genes had successfully identified mutations in LSD patients with low or undetected enzyme activity. Twenty-three (23) mutations associated with LSD were identified in Malaysia (Table 3). The mutations detected include missense, nonsense, small deletions, duplications and splicing. In patients with MLD, three missense mutations, c,116dupg p.(Cys40Leufs 36 ), c.746 T > C p.(Phe249Ser) and c.922T >C p.(Tyr308His) were observed in ARSA gene which were also reported in patients with metachromatic leukodystrophy [12, 13].

Among the patients with Pompe disease, five missense mutations (c.1A > G p.(Met1Val), c.1561G > A p.(GLu521 Lys), c.1843G > A p.(Gly615Arg), c.1935C > A p. (Asp645Glu) and c.2238G > C p.(Trp746Cys)), two small nucleotide deletions (c.2815_2816delGT p.(Val939Leufs*78) and c.2024_2026delACA p.(Asn675del)) were detected in GAA gene. One patient demonstrated a splice site mutation at c. $1551+1 \mathrm{G}>\mathrm{A}$ in $G A A$ gene. This mutation is at canonical splice site sequences that may lead to exon skipping during pre-MRNA splicing and eventually resulting in aberrant protein synthesis.

In patients with MPS IVA, one splicing mutation (c.1364 + $1 \mathrm{G}>\mathrm{A}$ ) p.(?), two missense mutations c.953T > G p.(Met318Arg) and c.503G > T p.(Gly168Val), one small nucleotides deletion c.106-111delCTGCTC p.(?) and 3 nonsense mutations c.473_477delAGTGG p.(Glu158Valfs*12), c.551G > A p.(Trp184*) and c.502G > T p.(Gly168*l) were found in GALNS gene. Most of the mutations were found to be clustered in exon 5 of GALNS gene. While in Gaucher, c.1389-3 C > G p.(?), c.1448T > G p.(Leu483Arg) and c.1448 T > C p.(Leu483Pro) mutations were detected in GBA gene.

With respect to Fucosidosis, two homozygous nonsense mutations were presented in four unrelated patients, c.393T >A p.(Tyr131*) and c.1295G >A p. (Trp432*) in FUCA1 gene. Changes from T to A at nucleotide 393 was predicted to create a truncated $a$-L-fucosidase protein. This mutation was previously reported in two separate studies, involving patients of Chinese origin [14, 15]. The c.1295G > A mutation caused substitution from amino acid Trp to a stop codon that subsequently led to a truncated protein. This mutation is located in a highly conserved region.

Table 3 also shows distribution of the selected LSD mutations in Malaysian ethnicity. Pompe disorder was mainly presented in Chinese ethnicity. The three distinct mutations in GBA gene were found only in Malay ethnicity. As for MPS IVA, the mutation c.473_477delAGTGG and c.502G > T were found only in Malay ethnicity whereas mutation c. $218 \mathrm{~A}>\mathrm{G}$ and c.551G $>$ A were revealed in Indian ethnicity. Meanwhile, a few numbers of patients from Chinese descendant showed mutation c.106-111delCTGCTC and c.953T > G. Interestingly, fucosidosis mainly presented in three unrelated Iban patients and inherited from the parents involving homozygous p.(Trp432*) mutation in FUCA1gene.

\section{Discussion}

Our analysis suggested that the prevalence of LSD in Malaysia is quite low compared with the other four countries and the carrier frequencies is $1: 241$. We also observed that the most prevalent LSD subtype for MPS and sphingolipidoses in Malaysia were MPS II and Fabry, and the most prominent nucleotide change was Fucosidosis with c. $1295 \mathrm{G}>\mathrm{A}$.

During the last 15 years, we are the only laboratory offering confirmational test for LSD in Malaysia. Our institution is currently the only centre with comprehensive LSD diagnostic tests comprises of screening and confirmatory tests in Malaysia. In addition, we also include two university hospitals (one in the Klang Valley and one in East Coast region), which provide the screening of MPS and send the presumptive patients' samples to us for confirmation. Majority of the most clinically suspected cases were from central region which mainly from Klang Valley. Therefore, a time tendency for a more uniform coverage of the country by our laboratory has been observed. Most clinically suspected cases from all part in Malaysia are referred to our centre for confirmatory diagnosis. Thus, our data highly reflective of the status of LSD in Malaysia. Furthermore, our data is the only representative data for LSD status in Malaysia as all clinically suspected cases from all part in Malaysia were referred to us.

The low prevalence of LSD maybe due to short period of data retrieval (2008-2017). The study of prevalence of LSD in The Netherlands [2], Czech Republic [16], United Arab Emirates (UAE) [17] and Northern Portugal [1], took more than 20 years. Clinical suspicion of LSD in patients among medical health practitioner especially general physician and paediatrician in Malaysia is still low and should be addressed by the respective authorities. Increase awareness of LSD and sufficient laboratory facilities can help in detecting underdiagnosed patients. Geographical factor also plays some role as some patients from very remote areas may have difficulties to access the medical facilities. This may had underestimated the prevalence of LSD in this region.

In Malaysia, mucopolysaccharidoses was the most common type of LSD (47 of 92 patients, or 51\%) with the prevalence of 1 in 292,401 live births. MPS Type II accounted the most among other MPS which showed similarity with China [18] and Taiwan [19]. Although sphingolipidoses were not common (0.13 per 100,000), prevalence of Fabry disease was almost similar to The Netherlands [2] and twice higher than UAE [17]. 
Over a 10-year period from 2008 to 2017 , fucosidosis was the only disease detected $(n=4)$ in the oligosaccharidosis group. It was noted to be $\sim 2$-fold higher than in the Netherlands [2]. However, when comparing to UAE, the prevalence of fucosidosis in UAE was 20-fold higher than Malaysia [17]. This is most likely due to consanguinity that leads to a higher birth prevalence in autosomal recessive diseases with a presence of a 'founder mutation' in the ethnic group, as it is known that consanguineous marriage among Emiratis is common [17]. In this study, we observed that three out of four patients with fucosidosis originated from the state of Sarawak. The p.(Trp432*) mutation which caused amino acid substitution from Trp to stop codon in exon 8 of FUCA1 gene is predicted to cause a truncated protein [20]. We believe that this findings may support our hypothesis of a founder gene p.(Trp432*) mutation among Sarawak population [21]. Holguin Province in Cuba has also been observed with highest incidence of fucosidosis with single mutation of p.(GIn422*) among its population [22].

Diagnosis of a few LSD appeared to be more delayed in Malaysia. For instance, the median age at diagnosis of MPS IVA and mucolipidoses type II in Malaysia were three times higher compared to Australia (9.3 years vs 2.7 years and 2.5 years vs 0.8 years respectively) [23]. Median age at diagnosis of MPS IIB (2.1 years vs 3.5 years) and Gaucher ( 4.5 years vs 9.5 years) were also higher than Australia. However, the range of age diagnosis in Malaysia was quite narrow compared to Australia (MPS IIIB: 1.17-3 years vs 0-21.4 years; Gaucher: 0.14-7 years vs 0-78.2 years) which maybe due to time of presentation of patient to the clinic. As for MPS I, MPS II, Pompe and MLD, the median age of diagnosis was almost similar between Malaysia and Australia. These results highlight that there is delay in the diagnosis of LSD in Malaysia.

We found that MLD was more common in the Iban ethnic population from Sarawak, while Pompe disease was more frequent in Chinese. The Iban population were 44 times more likely to have MLD compared to the non-lban population (OR 43.53, 95\% Cl 15.29-123.93, p<0.05). Therefore, the prevalence of MLD among the Iban population was estimated to be 1 in 6,981 or 14:100,000 live births. Few other studies have been conducted among ethnic populations around the world. Holve et al [24] reported that the incidence of MLD among Navajo tribes in United States was 1 in 2,520 live births, while the Habbanite Jews constituted a high-risk population for MLD with a reported incidence of 1 in 75 live births [25]. We were unable to calculate the prevalence of Pompe among the Chinese population due to inadequate data of live births among that population between 1988 to 2000 .

\section{Conclusions}

These data are the first to describe the prevalence, frequency and demographic data of patients diagnosed with LSD in Malaysia. In summary, LSD as a group, can be considered as not uncommon inborn error of metabolism in Malaysia with prominent certain types of LSD in certain ethnic; Pompe in Chinese community and MLD in Iban population. A more comprehensive study on the prevalence of LSD in Malaysia may provide valuable information.

\section{Declarations}

\section{Ethical approval and consent to participate}

The need for approval was waived by the local ethical committee (Medical Review \& Ethics Committee - MREC, Ministry of Health, Malaysia) as data were collected retrospectively and reported anonymously.

\section{Consent for publication}

Not applicable.

\section{Availability of data and materials}

The datasets used and/or analysed during the current study are available from the corresponding author after getting approval from the Director General of Health from Ministry of Health Malaysia.

\section{Competing interest}

All the authors declare that they have no conflict of interest disclose.

\section{Funding}

This research did not receive any specific grant from the funding agencies in the public, commercial, or not-for-profit sectors. Diagnostic testing for LSD were funded under operational budget, Ministry of Health Malaysia.

\section{Authors' contribution}

A.O.: conception, design, manuscript writing; R.M.: biochemical analysis, manuscript correction; F.D.A.N.: statistical analysis, manuscript correction; N.M.S.: biochemical analysis, manuscript correction; S.M.N.: manuscript correction; N.S.S.: manuscript correction; N.A.A.A.: molecular analysis, manuscript correction; S.A.A.W.: molecular analysis, manuscript correction; L.S.H.: molecular analysis, manuscript correction; Y.Y.: molecular analysis, manuscript correction; J.A.J.: conception, design, manuscript writing.

\section{Acknowledgements}


The authors would like to express our gratitude to the Director General of Health Malaysia, Ministry of Health Malaysia for permission to publish this paper. Our special thanks to all staff of Inborn Errors of Metabolism \& Genetics Unit, Biochemistry Unit and Molecular Diagnostic Unit for their technical assistance.

We thank Dr Wan Rozita Wan Mahiyudin and Dr Salina Abdul Rahman for critical reading of the manuscript and valuable comments. The results of this study have been presented as a poster presentation in the $3^{\text {rd }}$ ASEAN Congress on Medical Biotechnology and Molecular Biosciences at The Gurney Resort Hotel \& Residence, Penang on 9-10 July 2018.

\section{References}

1. Pinto R, Caseiro C, Lemos M, et al, Prevalence of lysosomal storage diseases in Portugal, Eur. J. Hum. Genet. 12 (2004) 87-92; doi: 10.1038/sj.ejhg.5201044. PMID: 14685153.

2. Poorthuis BJ, Wevers RA, Kleijer WJ, et al, The frequency of lysosomal diseases in The Netherlands, Hum. Genet. 105 (1999) 151-156; doi: 10.1007/s004399900075. PMID: 10480370.

3. Omar A, Jalil JA, Shakrin NM, Ngu LH, Yunus ZM. Selective screening for detection of mucopolysaccharidoses in Malaysia: A two-year study (20142016), Mol. Genet Metab Rep. 2019;19:100469. doi:10.1016/j.ymgmr.2019.100469. PMID: 31193155; PMCID: PMC6517573.

4. Omar A, Jalil JA, Shakrin NM, Ngu LH, Yunus ZM. Demographic, laboratory findings and diagnostic evaluation among high-risk patients with mucopolysaccharidosis in Malaysia. Data in Brief. 2019;25:104377. doi:10.1016/j.dib.2019.104377. PMID: 31516928; PMCID: PMC6728261.

5. Scriver CRBAL, Sly WS, Valle D, Childs R, Kinzler KW. The Metabolic Basis of Inherited Disease, Eighth eds. New York: McGraw-Hill; 2001.

6. Al-Thihli K, Al-Murshedi F, Al-Hashmi N, Al-Mamari W, Mazharul Islam M, Al-Yahyaee SA. Consanguinity, Endogamy and Inborn Errors of Metabolism in Oman: A Cross-Sectional Study. Hum Hered. 2014;77:183-8. doi: 10.1159/000362686. Epub 2014 Jul 29. PMID: 25060282.

7. Van den Hout JM, Kamphoven JH, Winkel LP, Arts WF, De Klerk JB, Loonen MC, Vulto AG, Cromme-Dijkhuis A, Weisglas-Kuperus N, Hop W, Van Hirtum H, Van Diggeles OP, Boer M, Kroos MA, Van Doorn PA, Van der Voort E, Sibbles B, Van Corven EJ, Brakenhoff JP, Van Hove J, Smeitink JA, de Jong G, Reuser AJ, Van der Ploeg AT, Long-term intravenous treatment of Pompe disease with recombinant human a-glucosidase from milk, Pediatr. 113 (2004) e448e457; doi: 10.1542/peds.113.5.e448. PMID: 15121988.

8. Barton NW, Brady RO, Dambrosia JM, Di Bisceglie AM, Doppelt SH, Hill SC, Mankin HJ, Murray GJ, Parker RI, Argoff CE, et al, Replacement therapy for inherited enzyme deficiency - macrophage-targeted glucocerebrosidase for Gaucher's disease, N. Engl. J. Med. 324 (2002) 1464-1470; doi: 10.1056/NEJM199105233242104. PMID: 2023606.

9. Beck M, Agalsidase alfa - a preparation for enzyme replacement therapy in Anderson-Fabry disease, Expert. Opin. Investig. Drugs 11 (2002) $851-858$; doi: 10.1517/13543784.11.6.851. PMID: 12036428.

10. Shafie AA, Supian A, Ahmad Hassali MA, Ngu LH, Thong MK, Ayob H, Chaiyakunapruk N. Rare disease in Malaysia: Challenges and solutions. PLoS One. 2020 Apr 2;15(4):e0230850. doi: 10.1371/journal.pone.0230850. PMID: 32240232; PMCID: PMC7117672.

11. Department of Statistics Malaysia, Pocket Stats. (as at Q3 2018), Series $1 / 2018$ https://www.dosm.gov.my/v1/uploads/files/7_Publication/Infographic/PocketStats/2018/Pocket_Stats_2018.pdf (accessed 15 June 2019).

12. Olkhovich NV, Takamura N, Pichkur NA, Gorovenko NG, Aoyagi K, Yamashita S. Novel mutations in arylsulfatase A gene in three Ukrainian families with metachromatic leukodystrophy. Mol Genet Metab. 2003;80(3):360-3. https://doi.org/10.1016/j.ymgme.2003.08.004.

13. Eng B, Nakamura LS, O’Reilly N, Schokman N, Nowaczyk MJ, Krivit W, Waye JS. Identification of nine novel arylsulfatase A (ARSA) gene mutations in patients with Metachromatic Leukodystrophy (MLD), Hum. Mutat. 2003;22(5):418-27. https://doi.org/10.1002/humu.9190.

14. Ip P, Goh W, Chan KW, Cheung PT. A novel FUCA1 mutation causing Fucosidosis in a Chinese boy. J Inherit Metab Dis. 2002;25:415-6. https://doi.org/10.1023/A:1020116220624.

15. Lin SP, Chang JH, de la Cadena MP, Chang TF, Lee-Chen GJ, Mutation identification and characterization of a Taiwanese patient with fucosidosis, J. Hum. Genet. 52(6) (2007) 553-556. https://doi.org/10.1007/s10038-007-0136-3. Epub 2007 Apr 11. PMID: 17427030.

16. Poupetova H, Ledvinova J, Berna L, Dvorakova L, Kozich V, Elleder M. The birth prevalence of lysosomal storage disorders in the Czech Republic: comparison with data in different populations. J Inherit Metab Dis. 2010;33:387-96. doi:10.1007/s10545-010-9093-7. Epub 2010 May 20. PMID: 20490927; PMCID: PMC2903693.

17. Al-Jasmi FA, Tawfig N, Berniah A, Ali BS, Taleb M, Hertecant JL, Bastaki F, Souid AK, Prevalence and novel mutations of lysosomal storage disorders in United Arab Emirates: LSD in UAE, J. Inherit. Metab. Rep. 10 (2013) 1-9; doi: 10.1007/8904_2012_182. Epub 2013 Jan 1. PMID: 23430803; PMCID: PMC3755583.

18. Chen X, Qiu W, Ye J, Han L, Gu X, Zhang H. Demographic characteristics and distribution of lysosomal storage disorder subtypes in Eastern China. J Hum Genet. 2016;61:345-9. doi:10.1038/jhg.2015.155. Epub 2016 Jan 7. PMID: 26740238.

19. Lin HY, Lin SP, Chuang CK, Niu DM, Chen MR, Tsai FJ, Chao MC, Chiu PC, Lin SJ, Tsai LP, Hwu WL, Lin JL, Incidence of the mucopolysaccharidoses in Taiwan, 1984-2004, Am. J. Med. Genet. Part A 149A (2009) 960-964; doi: 10.1002/ajmg.a.32781. PMID: 19396827.

20. Siti Aishah AW, Yusnita Y, Zabedah MY, Affandi O, Ngu LH. A novel p.(Trp432*) mutation in FUCA1 gene causes Fucosidosis in three unrelated Iban patients. Poster presented at: 41st Annual Conference of the Malaysian Society for Biochemistry and Molecular Biology (MSBMS 2016); August 17-18, 2016; Kuala Lumpur, Malaysia.

21. Willems PJ, Seo H-C, Coucke P, Tonlorenzi R, O’Brien JS, Spectrum of mutations in fucosidosis, Eur. J. Hum. Genet. 7 (1999) 60-67; doi: 10.1038/sj.ejhg.5200272. PMID: 10094192.

22. Menendez-Sainz C, Gonzalez-Quevedo A, Gonzales-Garcia S, Pena-Sanchez M, Giugliani R, High proportion of mannosidosis and fucosidosis among lysosomal storage diseases in Cuba, Genet. \& Mol. Res. 11 (3) (2012) 2352-2359; doi: 10.4238/2012.August.13.9. PMID: 22911605.

Page 6/10 
23. Meikle PJ, Hopwood JJ, Clague AE, Carey WF, Prevalence of lysosomal storage disorders. J. Am. Med. Asso. 281 (1999) 249-254; doi: 10.1001/jama.281.3.249. PMID: 9918480.

24. Holve S, Hu D, McCandless SE, Metachromatic leukodystrophy in the Navajo: Fallout of the American-Indian wars of the nineteenth century, Am. J. Med. Genet. 101 (2001) 203-208; doi: 10.1002/ajmg.1362. PMID: 11424134.

25. Zlotogora J, Bach G, Barak Y, Elian E. Metachromatic leukodystrophy in the Habbanite Jews: High frequency in a genetic isolate and screening for heterozygotes. Am J Hum Genet. 1980;32:663-9. PMID: 6107044; PMCID: PMC1686099.

26. Mechtler TP, Stary S, Metz TF, De Jesús VR, Greber-Platzer S, Pollak A, Herkner KR, Streubel B, Kasper DC. Neonatal screening for lysosomal storage disorders: feasibility and incidence from a nationwide study in Austria, Lancet 379(9813) (2012 Jan 28) 335 - 41. https://doi.org/10.1016/S01406736(11)61266-X. Epub 2011 Nov 29. PMID: 22133539.

27. Hermans MMP, Graaff ED, Kroos MA, Wisselaar HA, Oostra BA, Reuser AJJ, Identification of a point mutation in the human lysosomal a-glucosidase gene causing infantile glycogenosis type II, Biochem. \& Biophys. Res. Commun. 179 (2) (1991) 919-926; doi: 10.1016/0006-291x(91)91906-s. PMID: 1898413.

28. Wan L, Lee CC, Hsu CM, Hwu WL, Yang CC, Tsai CH, Tsai FJ. Identification of eight novel mutations of the acid alpha-glucosidase gene causing the infantile or juvenile form of Glycogen Storage Disease type II. J Neurol. 2008;255(6):831-9. doi: 10.1007/s00415-008-0714-0. Epub 2008 May 6. PMID: 18458862.

29. Ko MT, Hwu TM, Lin YW, Tseng LH, Hwa HL, Wang TR, Chuang SM, Molecular Genetic study of Pompe Disease in Chinese patients in Taiwan, Hum. Mutat. 13 (1999) 380-384; doi: 10.1002/(SICI)1098-1004(1999)13:5<380::AID-HUMU6>3.0.C0;2-A. PMID: 10338092.

30. Hermans MM, Graaff E, Kroos MA, Wisselaar HA, Willemsen R, Oostra BA, Reuser AJJ. The conservative substitution Asp-645-Glu in lysosomal alphaglucosidase affects transport and phosphorylation of the enzyme in an adult patient with Glycogen Storage Disease type II. Biochem J. 1993;289:68793. https://doi.org/10.1042/bj2890687.

31. Shieh JJ, Lin CY, Frequent mutation in Chinese patients with infantile type of GSD II in Taiwan: evidence for a founder effect, Hum. Mutat. 11(4) (1998) 306 - 12. https://doi.org/10.1002/(SICI)1098-1004(1998)11:4<306::AID-HUMU8>3.0.C0;2-S. PMID: 9554747.

32. Bali SD, Goldstein JL, Banugaria S, Dai J, Mackey J, Rehder C, Priya SK. Predicting cross-reactive immunological material (CRIM) status in Pompe disease using GAA mutations: lesson learned from 10 years of clinical laboratory testing experience. Am J Med Genet Semin. 2012;15(160):40-9.

https://doi.org/10.1002/ajmg.c.31319. Epub 2012 Jan 17.

33. Suwannarat P, Keeratichamroen S, Wattanasirichaigoon D, et al. Molecular characterization of type 3 (neuronopathic) Gaucher disease in Thai patients. Blood Cells Mol Dis. 2007;39(3):348-52. doi:10.1016/j.bcmd.2007.06.015. Epub 2007 Aug 8. PMID: 17689991.

34. Tsuji S, Choudary PV, Martin BM, et al, A mutation in the human glucocerebrosidase gene in neuronopathic Gaucher's disease, N. Engl. J. Med. 316 (10) (1987) 570-575; doi: 10.1056/NEJM198703053161002. PMID: 2880291.

35. Uchiyama A, Tomatsu S, Kondo N, et al, New Gaucher disease mutations in exon 10: a novel L444R mutation produces a new Ncil site the same as L444P, Hum. Mol. Genet. 3 (7) (1994) 1183-1184; doi: 10.1093/hmg/3.7.1183. PMID: 7981693.

36. Bunge S, Kleijer WJ, Tylki-Szymanska A, Steglich C, Beck M, Tomatsu S, Fukuda S, Poorthuis BJ, Czartoryska B, Orii T, Gal A, Identification of 31 novel mutations in the $\mathrm{N}$-acetylgalactosamine-6-sulfatase gene reveals excessive allelic heterogeneity among patients with Morquio $A$ syndrome, Hum. Mutat. 10(3) (1997) 223-232; doi: 10.1002/(SICI)1098-1004(1997)10:3<223::AID-HUMU8>3.0.CO;2-J. PMID: 9298823.

37. Yang CF, Tsai FJ, Lin SP, Lee CC, Wu JY. A novel in-frame deletion mutation (c106-111del) identified in a Taiwan Chinese patient with type IVA mucopolysaccharidosis. Hum Mutat. 2001;18(3):254. https://doi.org/10.1002/humu.1187.

38. Ogawa T, Tomatsu S, Fukuda S, Yamagishi A, Rezvi GM, Sukegawa K, Kondo N, Suzuki Y, Shimozawa N, Oru T, Mucopolysaccharidosis IVA. screening and identification of mutations of the N-acetylgalactosamine-6-sulfate sulfatase gene. Hum Mol Genet. 1995;4(3):341-50.

https://doi.org/10.1093/hmg/4.3.341.

39. Leong YH, Nor Azimah AA, Chew HB, Keng WT, Thong MK, Mohd Khalid MKN, Hung LC, Norzila MZ, Azura R, Muzhirah AMH, Yusnita Y, Ngu LH. Clinical, biochemical and genetic profiles of patients with mucopolysaccharidosis type IVA (Morquio A syndrome) in Malaysia: the first national natural history cohort study. Orphanet J Rare Dis. 2019;14:143. doi:10.1186/s13023-019-1105-6. PMID: 31200731; PMCID: PMC6570902.

40. Lee NH, Cho SY, Maeng SH, Jeon TY, et al. Clinical, radiologic, and genetic features of Korean patients with Mucopolysaccharidosis IVA, Korean J Pediatr 55(11) (2012 Nov) 430-7. https://doi.org/10.3345/kjp.2012.55.11.430. Epub 2012 Nov 23.

41. Nor Azimah AA, Yusnita Y, Affandi O, Zabedah MY. Mutations in Arylsulfatase A Gene of Malaysian Patients with Metachromatic Leukodystrophy. Poster presented at: Human Genome Meeting 2015. Kuala Lumpur Convention Centre, 14-17 March 2015.

\section{Tables}




\begin{tabular}{|c|c|c|c|c|c|c|c|c|c|c|c|c|c|}
\hline \multirow[t]{2}{*}{ Disorders } & \multicolumn{3}{|c|}{ Gender (Frequency) } & \multicolumn{6}{|c|}{ Ethnicity (Frequency) } & \multicolumn{4}{|c|}{ Regional (Frequency) } \\
\hline & Male & Female & Total & Malay & Chinese & Indian & $\begin{array}{l}\text { Sabah } \\
\text { Native }\end{array}$ & $\begin{array}{l}\text { Sarawak } \\
\text { Native }\end{array}$ & Others & Central & Northern & $\begin{array}{l}\text { East } \\
\text { Coast }\end{array}$ & Southern \\
\hline Total MPS & 29 & 18 & 47 & 32 & 0 & 2 & 3 & 1 & 0 & 25 & 9 & 4 & 3 \\
\hline MPS I & 2 & 5 & 7 & 4 & 1 & 0 & 2 & 1 & 0 & 1 & 0 & 2 & 0 \\
\hline MPS II & 15 & 0 & 15 & 14 & 0 & 0 & 0 & 0 & 0 & 8 & 4 & 2 & 0 \\
\hline MPS IIIA & 3 & 1 & 4 & 4 & 2 & 0 & 0 & 0 & 0 & 1 & 2 & 0 & 1 \\
\hline MPS IIIB & 0 & 2 & 2 & 0 & 4 & 0 & 0 & 0 & 0 & 1 & 0 & 0 & 1 \\
\hline MPS IVA & 5 & 5 & 10 & 5 & 2 & 1 & 0 & 0 & 0 & 8 & 2 & 0 & 0 \\
\hline MPS VI & 4 & 5 & 9 & 5 & 9 & 1 & 1 & 0 & 0 & 6 & 1 & 0 & 1 \\
\hline $\begin{array}{l}\text { Mucolipidoses } \\
\text { Type II }\end{array}$ & 0 & 5 & 5 & 5 & 0 & 0 & 0 & 0 & 0 & 1 & 1 & 1 & 2 \\
\hline Pompe & 4 & 5 & 9 & 0 & 7 & 2 & 0 & 0 & 0 & 6 & 2 & 0 & 0 \\
\hline $\begin{array}{l}\text { Total } \\
\text { Sphingolipidoses \& } \\
\text { Oligosaccharidoses }\end{array}$ & 18 & 13 & 31 & 16 & 3 & 0 & 1 & 10 & 1 & 9 & 5 & 3 & 1 \\
\hline Fucosidosis & 2 & 2 & 4 & 0 & 2 & 0 & 0 & 2 & 0 & 1 & 0 & 0 & 0 \\
\hline Gaucher & 1 & 3 & 4 & 4 & 0 & 0 & 0 & 0 & 0 & 2 & 0 & 0 & 1 \\
\hline GM1 & 2 & 2 & 4 & 4 & 0 & 0 & 0 & 0 & 0 & 4 & 0 & 0 & 0 \\
\hline GM2 (Sandhoff) & 2 & 0 & 2 & 1 & 0 & 0 & 1 & 0 & 0 & 0 & 1 & 0 & 0 \\
\hline MLD & 10 & 5 & 15 & 4 & 1 & 0 & 0 & 9 & 1 & 1 & 4 & 3 & 0 \\
\hline Fabry & 1 & 0 & 1 & 1 & 0 & 0 & 0 & 0 & 0 & 0 & 0 & 0 & 0 \\
\hline Krabbe & 0 & 1 & 1 & 1 & 0 & 0 & 0 & 0 & 0 & 1 & 0 & 0 & 0 \\
\hline Total LSD & 51 & 41 & 92 & 53 & 19 & 4 & 4 & 11 & 1 & 41 & 17 & 8 & 6 \\
\hline
\end{tabular}


Table 2

Birth prevalence of LSDs in Malaysia and comparison of data in different populations

\begin{tabular}{|c|c|c|c|c|c|c|c|c|c|c|}
\hline \multirow[t]{2}{*}{ Disease } & \multirow{2}{*}{$\begin{array}{l}\text { No. of } \\
\text { patients } \\
2008- \\
2017\end{array}$} & \multirow{2}{*}{$\begin{array}{l}\text { Years } \\
\text { of } \\
\text { birth }\end{array}$} & \multirow{2}{*}{$\begin{array}{l}\text { No. of live } \\
\text { births }\end{array}$} & \multirow{2}{*}{$\begin{array}{l}\text { Carrier } \\
\text { frequency^ }\end{array}$} & \multirow{2}{*}{$\begin{array}{l}\text { Birth } \\
\text { prevalence } \\
\text { (1 per } \\
\text { number of } \\
\text { live birth) }\end{array}$} & \multicolumn{5}{|c|}{ Birth prevalence (per 100,000$)$} \\
\hline & & & & & & $\begin{array}{l}\text { Malaysia } \\
\text { (Our } \\
\text { Centre) }\end{array}$ & $\begin{array}{l}\text { United } \\
\text { Arab } \\
\text { Emirates } \\
\text { (UAE) }\end{array}$ & $\begin{array}{l}\text { Czech } \\
\text { Republic }\end{array}$ & $\begin{array}{l}\text { Northern } \\
\text { Portugal }\end{array}$ & $\begin{array}{l}\text { The } \\
\text { Netherlands }\end{array}$ \\
\hline
\end{tabular}

\begin{tabular}{|c|c|c|c|c|c|c|c|c|c|c|}
\hline Mucolipidosis II & 5 & $\begin{array}{l}1994- \\
2015\end{array}$ & $11,147,581$ & 747 & $2,229,516$ & 0.04 & 1.35 & 0.22 & 0.81 & 0.16 \\
\hline Pompe & 9 & $\begin{array}{l}1988- \\
2017\end{array}$ & $15,251,705$ & 651 & $1,694,634$ & 0.06 & 2.66 & NA & 0.17 & 2.00 \\
\hline \multicolumn{11}{|c|}{ Oligosaccharidoses } \\
\hline Fucosidosis & 4 & $\begin{array}{l}2006- \\
2011\end{array}$ & $2,917,609$ & 427 & 729,402 & 0.14 & 2.02 & 0.00 & 0.00 & 0.05 \\
\hline $\begin{array}{l}\text { Sphingolipidoses } \\
\text { (all types) }\end{array}$ & 27 & $\begin{array}{l}1974- \\
2016\end{array}$ & $20,810,991$ & 439 & 770,777 & 0.13 & NA & 5.00 & 12.6 & 6.2 \\
\hline Gaucher & 4 & $\begin{array}{l}2009- \\
2017\end{array}$ & $4,550,140$ & 534 & $1,137,535$ & 0.09 & 0.25 & 1.13 & 1.35 & 1.16 \\
\hline $\mathrm{GM}_{1}$ & 4 & $\begin{array}{l}2002- \\
2016\end{array}$ & $7,403,711$ & 681 & $1,850,928$ & 0.05 & 4.66 & 0.26 & 0.62 & 0.41 \\
\hline $\mathrm{GM}_{2}$ (Sandhoff) & 2 & $\begin{array}{l}2010- \\
2013\end{array}$ & $1,983,105$ & 498 & 991,553 & 0.10 & 1.21 & 0.19 & 3.13 & 0.41 \\
\hline MLD & 15 & $\begin{array}{l}2000- \\
2014\end{array}$ & $7,417,704$ & 352 & 494,514 & 0.20 & 1.50 & 0.69 & 1.85 & 1.42 \\
\hline $\begin{array}{l}\text { MLD (Iban origin } \\
\text { only) }\end{array}$ & 9 & $\begin{array}{l}2009- \\
2013\end{array}$ & 62,825 & 42 & 6,981 & 14.33 & - & - & - & - \\
\hline Fabry & 1 & 1974 & $193,203^{*}$ & 220 & 193,203 & $0.52^{\star}$ & 0.25 & $1.00 *$ & 0.12 & $0.42^{\star}$ \\
\hline Krabbe & 1 & 2014 & 511,865 & 358 & 511,865 & 0.20 & 0.00 & 0.40 & 1.21 & 1.35 \\
\hline MPS (all types) & 47 & $\begin{array}{l}1990- \\
2016\end{array}$ & $13,742,837$ & 271 & 292,401 & 0.34 & NA & 3.72 & 4.80 & 4.50 \\
\hline MPS I & 7 & $\begin{array}{l}2010- \\
2016\end{array}$ & $3,524,309$ & 355 & 503,473 & 0.20 & 0.25 & 0.72 & 1.33 & 1.19 \\
\hline MPS II & 15 & $\begin{array}{l}2004- \\
2016\end{array}$ & $3,321,377^{*}$ & 236 & 221,425 & $0.45^{\star}$ & 0.00 & $0.83^{\star}$ & 1.09 & $1.30 *$ \\
\hline MPS IIIA & 4 & $\begin{array}{l}2003- \\
2015\end{array}$ & $6,400,970$ & 633 & $1,600,243$ & 0.06 & 0.00 & 0.47 & 0.00 & 1.16 \\
\hline MPS IIIB & 2 & $\begin{array}{l}2010- \\
2012\end{array}$ & $1,479,191$ & 431 & 739,596 & 0.14 & 1.05 & 0.02 & 0.72 & 0.42 \\
\hline MPS IVA & 10 & $\begin{array}{l}1990- \\
2014\end{array}$ & $12,713,498$ & 564 & $1,271,350$ & 0.08 & 1.41 & 0.71 & 0.60 & 0.22 \\
\hline MPS VI & 9 & $\begin{array}{l}1998- \\
2014\end{array}$ & $8,464,679$ & 485 & 940,520 & 0.11 & 2.51 & 0.05 & 0.42 & 0.15 \\
\hline Total LSD & 92 & $\begin{array}{l}1974- \\
2017\end{array}$ & $21,335,178$ & 241 & 231,904 & 0.43 & 26.87 & 12.25 & 25 & 14 \\
\hline
\end{tabular}


Table 3

Several genotypes detected in selected LSDs in Malaysia

\begin{tabular}{|c|c|c|c|c|c|c|c|}
\hline Disease & Phenotype & Gene & Nucleotide change & $\begin{array}{l}\text { Amino acid } \\
\text { changes }\end{array}$ & $\begin{array}{l}\text { Exon/ } \\
\text { Intron }\end{array}$ & Ethnicity* & References \\
\hline \multirow{14}{*}{$\begin{array}{l}\text { Pompe } \\
\text { OMIM } \\
232300\end{array}$} & \multirow[t]{14}{*}{ Cardiomyopathy } & \multirow[t]{14}{*}{ GAA } & c. $1551+1 G>A$ & p.(?) & IVS 10; & \multirow[t]{3}{*}{ Indian (1) } & [26] \\
\hline & & & c. $1561 G>A$ & p.(Glu521Lys) & & & [27] \\
\hline & & & & & 11 & & \\
\hline & & & c. $1843 \mathrm{G}>\mathrm{A}$ & p.(Gly615Arg) & 13 & \multirow{2}{*}{$\begin{array}{l}\text { Chinese } \\
(1)\end{array}$} & [29] \\
\hline & & & c. $2238 \mathrm{G}>\mathrm{C}$ & p.(Trp746Cys) & 16 & & [28] \\
\hline & & & c. $1843 \mathrm{G}>\mathrm{A}$ & p.(Gly615Arg) & 13 & \multirow{2}{*}{$\begin{array}{l}\text { Chinese } \\
\text { (1) }\end{array}$} & [29] \\
\hline & & & c.2815_2816delGT & $\stackrel{\text { p. }}{(\text { Val939Leufs*78) }}$ & 20 & & [29] \\
\hline & & & $\begin{array}{l}\text { c. } 1935 \mathrm{C}>\mathrm{A} \\
\text { (homozygous) }\end{array}$ & p.(Asp645Glu) & 14 & $\begin{array}{l}\text { Chinese } \\
\text { (1) }\end{array}$ & [30] \\
\hline & & & c. $1935 \mathrm{C}>\mathrm{A}$ & p.(Asp645Glu) & 14 & \multirow{2}{*}{$\begin{array}{l}\text { Chinese } \\
(1)\end{array}$} & [30] \\
\hline & & & c.2024_2026delACA & p.(Asn675del) & 14 & & [31] \\
\hline & & & c. $1935 \mathrm{C}>\mathrm{A}$ & p.(Asp645Glu) & 14 & $\begin{array}{l}\text { Chinese } \\
(1)\end{array}$ & [30] \\
\hline & & & c. $2238 \mathrm{G}>\mathrm{C}$ & p.(Trp746Cys) & 16 & & [28] \\
\hline & & & $\begin{array}{l}\text { c. } 1 A>G \\
\text { (homozygous) }\end{array}$ & p.(Met1Val) & 2 & Indian (1) & [32] \\
\hline & & & $\begin{array}{l}\text { c. } 1935 \mathrm{C}>\mathrm{A} \\
\text { (homozygous) }\end{array}$ & p.(Asp645Glu) & 14 & $\begin{array}{l}\text { Chinese } \\
(2)\end{array}$ & [30] \\
\hline \multirow{3}{*}{$\begin{array}{l}\text { Fucosidosis } \\
\text { OMIM } \\
230000\end{array}$} & \multirow[t]{3}{*}{ Hepatosplenomegaly, coarse facies } & \multirow[t]{3}{*}{ FUCA1 } & $\begin{array}{l}\text { c. } 393 T>A \\
\text { (homozygous) }\end{array}$ & p. $($ Tyr131*) & 2 & $\begin{array}{l}\text { Chinese } \\
(1)\end{array}$ & [14] \\
\hline & & & $\begin{array}{l}\text { c. } 1295 \mathrm{G}>\mathrm{A} \\
\text { (homozygous) }\end{array}$ & p. $\left(\operatorname{Trp} 432^{\star}\right)$ & 8 & $\begin{array}{l}\text { Chinese } \\
\text { (1) }\end{array}$ & [20] \\
\hline & & & $\begin{array}{l}\text { c. } 1295 \mathrm{G}>\mathrm{A} \\
\text { (homozygous) }\end{array}$ & p. $\left(\operatorname{Trp} 432^{*}\right)$ & 8 & Iban (2) & [20] \\
\hline \multirow{4}{*}{$\begin{array}{l}\text { Gaucher } \\
\text { OMIM } \\
230800\end{array}$} & \multirow[t]{4}{*}{ Hepatosplenomegaly } & \multirow[t]{4}{*}{ GBA } & c. $1389-3$ C > G & p.(?) & IVS 10 & \multirow[t]{2}{*}{ Malay (1) } & [33] \\
\hline & & & c. $1448 \mathrm{~T}>\mathrm{C}$ & p.(Leu483Pro) & 11 & & \\
\hline & & & c. $1448 \mathrm{~T}>\mathrm{C}$ & p.(Leu483Pro) & 11 & \multirow[t]{2}{*}{ Malay (1) } & [34] \\
\hline & & & c. $1448 \mathrm{~T}>\mathrm{G}$ & p.(Leu483Arg) & 11 & & [35] \\
\hline \multirow{2}{*}{$\begin{array}{l}\text { MLD } \\
\text { OMIM } \\
250100\end{array}$} & \multirow[t]{2}{*}{ Neuro regression, leukodystrophy } & \multirow[t]{2}{*}{ ARSA } & $\begin{array}{l}\text { c.746 T > C } \\
\text { (homozygous) }\end{array}$ & p.(Phe249Ser) & 4 & Malay (1) & [12] \\
\hline & & & $\begin{array}{l}\text { c. } 116 \text { dupG } \\
\text { c. } 922 T>C\end{array}$ & $\begin{array}{l}\text { p. } \\
\text { (Cys40Leufs*36) } \\
\text { p.(Tyr308His) }\end{array}$ & $\begin{array}{l}1 \\
5\end{array}$ & Malay (1) & {$\left[\begin{array}{l}{[41]} \\
{[13]}\end{array}\right.$} \\
\hline \multirow{8}{*}{$\begin{array}{l}\text { MPS IVA } \\
\text { OMIM } \\
253000\end{array}$} & \multirow[t]{8}{*}{$\begin{array}{l}\text { Coarse facies, Clawed hand, scoliosis, } \\
\text { kyphoscoliosis }\end{array}$} & \multirow[t]{8}{*}{ GALNS } & c.473_477delAGTGG & p. & 5 & Malay (2) & [39] \\
\hline & & & c. $1364+1 \mathrm{G}>\mathrm{A}$ & p.(?) & IVS 12 & & [36] \\
\hline & & & c. $218 \mathrm{~A}>\mathrm{G}$ & p.(Tyr73Cys) & 2 & India (1) & {$[40]$} \\
\hline & & & c. $551 \mathrm{G}>\mathrm{A}$ & p. $\left(\operatorname{Trp} 184^{\star}\right)$ & 5 & & [39] \\
\hline & & & c.106_111delCTGCTC & p.(?) & 1 & $\begin{array}{l}\text { Chinese } \\
(2)\end{array}$ & [37] \\
\hline & & & c. $953 \mathrm{~T}>\mathrm{G}$ & p.(Met318Arg) & 9 & & [38] \\
\hline & & & c. $502 \mathrm{G}>\mathrm{T}$ & p.(Gly168*) & 5 & Malay (1) & [39] \\
\hline & & & c. $503 \mathrm{G}>\mathrm{T}$ & p.(Gly168Val) & 5 & & [39] \\
\hline
\end{tabular}

